\title{
The Nature of the Political Interaction between Israel and Saudi Arabia in the 21st Century
}

\author{
Roman Vladimirovich Penkovtsev ${ }^{1}$, Timur Vasilevich Gafurov ${ }^{1} \&$ Natalia Aleksandrovna Shibanova ${ }^{1}$ \\ ${ }^{1}$ Kazan Federal University, Russia \\ Correspondence: Roman Vladimirovich Penkovtsev, Kazan Federal University, Russia. E-mail: \\ RomanPenkovtsev@kpfu.ru
}

Received: June 9, 2019

doi:10.5539/jpl.v12n5p53
Accepted: August 25, $2019 \quad$ Online Published: August 31, 2019

URL: https://doi.org/10.5539/jpl.v12n5p53

\begin{abstract}
This paper considers the issue of interaction between two states, which are largely political antagonists: Israel and Saudi Arabia. The nature of the interaction between these states on the world political arena is of serious scientific and practical interest. Contrary to popular stereotypes, Israel maintains relations with many countries of the Arab world, and Saudi Arabia is no exception. It should be noted that a certain rapprochement of positions between these states occurred due to the activation on the geopolitical map of the Middle East of such an actor as Iran, which in the 21 st century energetically implements its nuclear program, accelerates economic development programs, and is generally focused on strengthening its role and places in the international arena. The US position represented by the administrations of B. Obama and D. Trump influenced to a large extent the process of intensifying interaction between Israel and Saudi Arabia, which stimulated the rapprochement of the positions of these two states on the "Syrian" and "Iranian" problems. In addition, it is worth paying attention to the establishment of similar positions between Israel and Saudi Arabia on the "Palestinian issue. "
\end{abstract}

Keywords: international relations, regional security, international terrorism, Arab spring, Israel, Saudi Arabia, USA

\section{Introduction}

Since the formation of the independent Jewish state of Israel, Saudi Arabia, along with the League of Arab States, has been fighting for the rights of the Arab population in Palestine. The nature of this struggle was not only political but often it took a military connotation. Often, hostilities in Palestine against Israel were led directly by Saudi Arabia, providing logistical assistance to countries in the League of Arab States. Basically, Saudi-Israeli relations have been modified in accordance with the volatile political situation in the Middle East. Currently, Saudi Arabia and Israel do not have an officially fixed relationship, but, like any rule, there are exceptions. This is precisely the situation we can observe by looking at the dynamics of the development of relations between Saudi Arabia and Israel. At the beginning of the 21st century, the nature of political relations between Saudi Arabia and Israel markedly transformed. Many changes were the result of the destabilization of the situation in the Middle East in the context of the "Arab spring" events, as well as the strengthening of the "Iranian factor" in the region. Iran's policy, directly or indirectly, facilitates the establishment of relations between Saudi Arabia and Israel.

\section{Methods}

There is a relatively small number of works on the issue of regional cooperation between Saudi Arabia and Israel. Of undoubted scientific interest for researchers is the work by D. V. Kuznetsov "Problems of the Middle East and Public Opinion: Arab-Israeli Conflict" which stage-by-stage shows the process of formation and normalization of relations between the two states. The problem being studied in the press and electronic media is not widely publicized due to a lack of information, and also because of the unwillingness of the states to advertise their relations making them public.

\section{Results and Discussion}

In the 21st century, Saudi Arabia and Israel face roughly the same political problems and trends. In the sphere of domestic politics, both states are characterized by the presence of political forces ready to conduct violent actions to achieve their own goals. Of course, the nature of the political process in Israel and Saudi Arabia is markedly different at first glance. If in the case of Riyadh we are talking about a tough authoritarian regime that practically 
does not take any form, even insignificant, but nevertheless pluralism and competition, then to characterize Israel they often use two seemingly mutually exclusive concepts: "ethnic democracy" and "ethnocracy ". Nevertheless, the essence of the regime does not change from this: a significant restriction of the rights of the Arab population remains behind the external facade of the developed democratic system.

In addition, over the past decades, both states have been threatened by the environment in which they are located. Both Israel and Saudi Arabia took the position that the only way to protect themselves from their neighbours is either by forceful invasion of their borders (the cases of Yemen and Lebanon), or the organization of armed actions and coups on the hostile territory, as a result of which objectionable rulers would be displaced (Syria, Egypt, Libya). At the same time, Saudi Arabia and Israel have approximately the same set of opponents: Iran, Turkey, Qatar, Hamas in Gaza, as well as the Muslim Brotherhood, wherever they are. At the same time, both countries have the same allies - the military-industrial elite of the USA and Great Britain.

The rapprochement of these two states from a purely political point of view is completely justified and rational. In modern geopolitical conditions, they have practically no alternatives except an alliance. However, the causes of this phenomenon raise a ton of questions. On the one hand, Saudi Arabia always positions itself as the main bastion of Islam in the whole world, seeks to spread its idea of religion in the minds of all Muslims. On the other hand, Riyadh agreed to provide Israel with its airspace should Israel decide to launch a bombing of the Islamic Republic of Iran. Moreover, in the long term we are talking about the purchase of Israeli rescue helicopters, refuelling vessels and drones that come from Israel through other regions, but only in a disassembled state. According to the corresponding member of the Russian Academy of Natural Sciences V. Mikhin, "the facts quite eloquently indicate that now Riyadh is desperately looking for allies in its struggle against Tehran". Despite these steps, Saudi Arabia is not yet ready to reveal its relations with Israel to the world.

The American factor plays a significant role in the escalation of conflicts in the Middle East. "For many modern military conflicts, the presence of a "backstage component" is characteristic. In such conflicts, the participation of the United States and its allies is not direct, open, but latent. In them, the White House, having a high rank in the conflict, acts not as a direct opponent, but as an organizer, accomplice, initiator or mediator depending on the interests pursued".

It should also be noted that while Barack Obama's cabinet was in power in the United States, relations between Saudi Arabia and Israel improved significantly due to their forced rapprochement and the loss of US positions in the Middle East. The rule of President Barack Obama in the historical sense seems to be sluggish and inconsistent including this was evident in the conduct of business with states and monarchies of the Middle East. Obama made an emphasis on the creation of a Palestinian state, and that, according to Washington, was to establish a lasting peace in the Middle East. He also adopted a tough policy regarding Israeli settlements in the West Bank. The pressure was carried out on Israel and in terms of the non-use of force against Iran. Under pressure, B. Netanyahu agreed to make concessions, but a number of conditions were put forward, including the recognition of Israel by Palestine as a "national state of the Jewish people", as well as the complete demilitarization of Palestine.

Obama's actions were negatively perceived by the Arab world, and the conditions put forward by Netanyahu were unacceptable to the Palestinian people. On this occasion, in one of the articles by the leading researcher at the Institute of Oriental Studies of the Russian Academy of Sciences, A. B. Podtserob, the spokesman for the head of the Palestinian National Autonomy N. Abu Rudein was quoted: "Netanyahu's comments sabotage all initiatives, paralyze all efforts made and challenge the positions of Palestinians, Arabs and Americans". Nevertheless, Obama said that he was set on a "friendship course" with Israel; he always adhered to it and was not going to spoil relations with Israel because of the hopes placed on him by influential Jewish voters - members of the Jewish lobby. Secretly, Obama ordered to finance Palestine, as there was a threat of destabilization in the Hamas region. On the whole, the issue of a peaceful settlement of this conflict continues to be an edge, despite Obama's promises made, including during his visit to Cairo. The fact that the task of recognizing Palestine and ending hostility between Arabs and Jews, will not be solved within the term of his presidency becomes clear since the moment of his phrase from his speech: "We cannot impose peace".

To summarize Obama's rule, the following can be said. While Barack Obama was in power, his authority in the Middle East increased, especially in Saudi Arabia, Israel, and Egypt. However, the United States failed to find mutual understanding with Iran regarding the issue of the nuclear program. The wide range of actions on the part of the United States, as well as their unwillingness to resolve the issue of Iran's destabilization of the situation in the Middle East peacefully, caused the rapprochement between Israel and Saudi Arabia.

At the moment, Donald Trump is in power in the US. With his "whims," he is a US president who may only ruin the already precarious peace between Israel and Saudi Arabia. Consider this statement as an example of Trump's 
visit to Saudi Arabia in May 2017 which resulted in the signing of a multi-million dollar contract for the supply of weapons and the latest equipment, which naturally aroused Israeli concern. This move could allow Riyadh to destabilize the Middle East and begin to escalate the conflict which was only recently moderated. At a May 2017 visit by US President Donald Trump to Israel, questions were discussed about Israel's ownership of Jerusalem, the establishment of relations with Palestine, and Netanyahu was concerned about Trump's reckless actions to provide US weapons to Saudi Arabia.

Thus, we can conclude that the attitudes of Saudi Arabia and Israel to the Iranian issue, to the readiness to take any measures on preventing the spread of the "Arab spring" sentiments in the Middle East region and to terminate the activities of Islamic organizations in the region, is quite aggressive. At the same time, the main task of the union of these states is to terminate Iran's program to destabilize the situation in the modern Middle East.

Great changes for regional relations between Middle East states can be brought by the Saudi Arabia Reform Program "Vision 2030", as well as its course on economic restructuring, namely the transition to renewable energy sources, which contains all the prerequisites for mutual and long-term cooperation of the powers. This reforming of the country involves deep economic transformations related to the lack of budget, much of which goes to the opposition of the terrorist threat that has arisen recently in the territory of the modern Middle East. In other words, a proposal was put forward "to reduce the costs of the management apparatus and increase the efficiency of resource use".

In anticipation of forthcoming economic changes, the ruling monarch said that the Saudi economy should become an economy of investment. It is worth noting the fact that tourism will become one of the main pillars of the kingdom economy. The greatest emphasis will be placed on attracting more pilgrims to the shrines of Saudi Arabia. The second aspect of reform is the transformation of government structures. In February 2015, at the initiative of the monarch, the following councils were created: the Council on Economics and Development (which task is to oversee the economic and social ministries and departments) and the Council on Politics and Security (the spectrum of which was the structure of internal political departments, the ministry of emergency situations and special services), who was led by Muhammad bin Naef. During this period, the policy of combating international terrorism became more actively implemented. Tolerance and latitude in religion have also become encouraged. In this regard, it is worth mentioning one of the provisions, which states that "the location of the Kingdom is the source from which the three monotheistic religions were born".

\section{Summary}

Undoubtedly, today Saudi Arabia refuses to disclose its relations with Israel due to long-standing religious feud and some territorial contradictions. The relations of these two states in the political sphere can be characterized by the epithet "the enemy of my enemy is my friend". The potential possibility of acquiring nuclear weapons by the Islamic Republic of Iran, the formation of Shia terrorist militias in Yemen, Iraq and on the borders of these states, the beginning of negotiations between world powers on Iranian nuclear weapons - all this must be considered the starting point of the rapprochement between Israel and Saudi Arabia.

It is also worth noting the beginning of cooperation between antagonist states in the military-political sphere due to the deterioration of relations with Qatar. The deterioration of relations between the Kingdom of Saudi Arabia and Qatar occurred in 2014, when armed conflict broke out in Syria, i.e. in the territory of the modern Middle East. Shortly before the start of the conflict, it was planned to lay a gas pipeline through Syria to European countries, but the gas pipeline agreement was never implemented between Qatar and the Kingdom of Saudi Arabia due to a number of contradictions. Firstly, Qatar sponsors the Muslim Brotherhood terrorist group. This destabilizes the situation on the borders of Saudi Arabia and Israel and causes dissatisfaction on the part of Riyadh. Secondly, this is the formation in the Middle East of a new alliance of forces, the so-called "Sunni NATO", which included states such as Saudi Arabia, Israel and Egypt. The purpose of this association is to cooperate in the military-political sphere, aimed at stabilizing the situation in the Middle East by countering the threats of terrorism.

An important issue is an interaction of states in the fight against the "common threat to security", which presents the "Iranian problem". In fairness, it should be noted that in the eyes of Iran, the regional influence of Saudi Arabia is seen as a serious threat that falls into the category of "unresolved problems with neighbours". While Israel and Saudi Arabia perceive Tehran solely as an adversary, but Qatar perceives it friendly, and repeated meetings of Qatar and Iran state leaders and their energy cooperation are proof of this, what in turn causes a lot of indignation from Riyadh. 


\section{Conclusions}

Thus, in the 21st century, Saudi Arabia's foreign policy strategy is being actively reformed; the process of forming new principles of policy and state governance is underway, what could favourably affect the formation and strengthening of bilateral relations with the State of Israel. The rapprochement of the positions of these two states is also explained by the appearance on the map of a new player embodied in Iran, which is striving to take a leadership position in the Middle East. Reluctance to see Iran as a leader explains much about nucleation of a political "union bloc" in the Middle East. Confirmation of this trend is a series of secret meetings of Israeli and Saudi politicians of various ranks held over the past few years in Italy, the Czech Republic and India. The main topic of contacts was the development of joint methods of "peaceful" pressure on Iran. At present, the situation is characterized by high dynamics and inconstancy and it is difficult to predict how durable such an alliance of states can be within the framework of such a "specific" bloc, but there are undoubtedly political trends for this.

\section{Acknowledgements}

The work is performed according to the Russian Government Program of Competitive Growth of Kazan Federal University.

\section{References}

Amour, P. O. (2017). Israel, the Arab Spring, and the unfolding regional order in the Middle East: a strategic assessment. British Journal of Middle Eastern Studies, 44(3), 293-309. https://doi.org/10.1080/13530194.2016.1185696

Jones, C., \& Guzansky, Y. (2017). Israel's relations with the Gulf states: Toward the emergence of a tacit security regime? Contemporary Security Policy, 38(3), 398-419. https://doi.org/10.1080/13523260.2017.1292375

Kosach, G. G. (2009). Barack Obama at Cairo University: a speech addressed to the Arab and Muslim world. Institute of the Middle East. Retrieved from http://www. iimes. ru/?p=8763

Kuznetsov, D. V. (2009). Problems of the Middle East and public opinion. Part I: Arab-Israeli conflict. Blagoveshchensk: Publishing House of BSPU.

Mikhin, V. (2014). Saudi Arabia - Israel: The Outlines of a New Union. IA REX. News Agency. Retrieved from http://www. iarex. ru/articles/47065.html

Mossallanejad. (2017). Trump's middle east policy making and the future of security. Geopolitics Quarterly, 12(4), 39-65.

Penkovtsev, R. V., \& Shibanova, N. A. (2015). Wars and Military Conflicts of the XXI Century in the Context of the Strategic Interests of the United States. Journal of Sustainable Development, 8(4), 164-168. https://doi.org/10.5539/jsd.v8n4p164

Podtserob, A. B. (2009). Barack Obama and US Politics in the Middle East. Institute of the Middle East. Retrieved from http://www. iimes. ru/?p=8903

Reznikov, A., \& Fedoseev, R. (2009). Israel is deaf to Obama. Glance. Business newspaper, June 5. Retrieved from http://www.vz. ru/politics/2009/6/5/294553.html

Serag, Y. (2017). Violent and Nonviolent Changes in the Images of Cities in the Arab Spring Countries. IOP $\begin{array}{lllll}\text { Conference } & \text { Series: }\end{array}$ https://doi.org/10.1088/1757-899X/245/7/072034

Shahidani, M. H., \& Penkovtsev, R. V. (2017). The Role of Social-Identity Beliefs in the Trends of Foreign Policy of Iran. Japanese Journal of Political Science, 18(3), 446-464. https://doi.org/10.1017/S1468109917000111

Vad, E. (2017). How to fight terrorism? Political and strategic aspects. CNS Spectrums, (10), 1-8.

\section{Copyrights}

Copyright for this article is retained by the author(s), with first publication rights granted to the journal.

This is an open-access article distributed under the terms and conditions of the Creative Commons Attribution license (http://creativecommons.org/licenses/by/4.0/). 